\title{
SUPERALLOYS FOR ULTRA SUPERCRITICAL STEAM TURBINES-OXIDATION BEHAVIOR
}

\author{
G.R. Holcomb \\ National Energy Technology Laboratory, U.S. Department of Energy, Albany, OR, USA \\ Keywords: Evaporation, Chromia, Steam Turbine, Steam Boiler, Breakaway Oxidation
}

\begin{abstract}
Goals of the U.S. Department of Energy's Advanced Power Systems Initiatives include power generation from coal at $60 \%$ efficiency, which requires steam conditions of up to $760{ }^{\circ} \mathrm{C}$ and $340 \mathrm{~atm}$, so called ultra-supercritical (USC) steam conditions. One of the important materials performance considerations is steam-side oxidation resistance. Evaporation of protective chromia scales is expected to be a primary corrosion mechanism under USC conditions. A methodology to calculate $\mathrm{Cr}$ evaporation rates from chromia scales with cylindrical geometries was developed that allows for the effects of $\mathrm{CrO}_{2}(\mathrm{OH})_{2}$ saturation within the gas phase. This approach was combined with $\mathrm{Cr}$ diffusion calculations within the alloy (with a constant flux of $\mathrm{Cr}$ leaving the alloy from evaporation) to predict $\mathrm{Cr}$ concentration profiles as a function of exposure time and to predict the time until the alloy surface concentration of $\mathrm{Cr}$ reaches zero. This time is a rough prediction of the time until breakaway oxidation. A hypothetical superheater tube, steam pipe, and high pressure turbine steam path was examined. At the highest temperatures and pressures, the time until breakaway oxidation was predicted to be quite short for the turbine blade, and of concern within the steam pipe and the higher temperature portions of the superheater tube. The predicted time until breakaway oxidation increases dramatically with decreases in temperature and total pressure. Possible mitigation techniques were discussed, including those used in solid oxide fuel cell metallic interconnects (lowering the activity of $\mathrm{Cr}$ in the oxide scale by adding $\mathrm{Mn}$ to the alloy), and thermal barrier coating use on high pressure turbine blades for both erosion and chromia evaporation protection.
\end{abstract}

\section{Introduction}

Goals of the U.S. Department of Energy's Advanced Power Systems Initiatives include power generation from coal at $60 \%$ efficiency, which requires steam conditions of up to $760{ }^{\circ} \mathrm{C}$ and $340 \mathrm{~atm}$, so called ultra-supercritical (USC) steam conditions. A limitation to achieving the goal is a lack of cost-effective metallic materials that can perform at these temperatures and pressures. Some of the more important performance limitations are high temperature creep strength, fire-side corrosion resistance, and steam-side oxidation resistance. Nickel-base superalloys are expected to be the materials best suited for steam boiler and turbine applications above about $675^{\circ} \mathrm{C}$ [1]. Specific alloys of interest include Haynes 230 and 282, Inconel 617, 625, 718, and 740, Nimonic 105, and Udimet 720Li. Alloy compositions are given in Table I.
Steam-side oxidation can result in several adverse conditions: general section loss from material thinning, deep localized section loss from internal oxidation (that may also provide crack initiation sites), dimensional changes that are critical in airfoils, and downstream erosion from oxide spallation. Evaporation of protective chromia scales may also be an issue at the higher temperatures and pressures of USC steam turbines. The evaporation of chromia scales in steam is the focus of the research presented here.

In prior work, a methodology to calculate the expected chromia evaporation rate as a function of temperature, pressure, gas velocity, and steam chemistry was developed [10] for chromia forming alloys used as steam turbine blades. The methodology was experimentally validated at low pressures and gas velocities by how well its kinetics predictions matched atmospheric pressure oxidation experiments in air plus water vapor environments. At $760{ }^{\circ} \mathrm{C}$ and $340 \mathrm{~atm}$, evaporation rates as high as $5.18 \times 10^{-8}$ $\mathrm{kg} / \mathrm{m}^{2} / \mathrm{s}$ of $\mathrm{CrO}_{2}(\mathrm{OH})_{2}(\mathrm{~g})$ were predicted for rotating high pressure (HP) turbine blade components [10]. This is equivalent to 0.080 $\mathrm{mm}$ per year of solid $\mathrm{Cr}$ loss. It was speculated that chromia evaporation upstream of the HP turbine, such as in the superheater, could partially saturate the steam with $\mathrm{CrO}_{2}(\mathrm{OH})_{2}(\mathrm{~g})$ and reduce the chromia evaporation rate.

The research presented here expands upon the prior work by 1) expanding the methodology from flat plate components to cylindrical geometries (such as found within superheaters and steam pipes), 2) linking the chromia evaporation in steam to $\mathrm{Cr}$ diffusion within the alloy to predict alloy $\mathrm{Cr}$ concentration profiles and breakaway oxidation times, 3) comparing these predictions to $\mathrm{Cr}$ concentration profiles found in laboratory experiments, and 4) applying the breakaway oxidation predictions to a hypothetical superheater-steam pipe-HP turbine steam path, where the effects of $\mathrm{CrO}_{2}(\mathrm{OH})_{2}(\mathrm{~g})$ saturation along the steam path are applied.

\section{Chromia Evaporation}

The oxidation of alloys protected by the formation of $\mathrm{Cr}_{2} \mathrm{O}_{3}$ (chromia formers) can undergo scale loss due to reactive evaporation of chromium-containing gas species. Water vapor increases the evaporation loss by allowing the formation of $\mathrm{CrO}_{2}(\mathrm{OH})_{2}(\mathrm{~g})$, which for these conditions has a higher vapor pressure than $\mathrm{CrO}_{3}(\mathrm{~g}) . \mathrm{CrO}_{3}(\mathrm{~g})$ is the predominate $\mathrm{Cr}$ gas specie in dry air or oxygen. The formation of $\mathrm{CrO}_{2}(\mathrm{OH})_{2}(\mathrm{~g})$ can be written as:

$$
1 / 2 \mathrm{Cr}_{2} \mathrm{O}_{3}(\mathrm{~s})+\mathrm{H}_{2} \mathrm{O}(\mathrm{g})+3 / 4 \mathrm{O}_{2}(\mathrm{~g})=\mathrm{CrO}_{2}(\mathrm{OH})_{2}(\mathrm{~g})
$$


Table I. Alloy Composition, Density, and Bulk Alloy Cr Concentration $\left(\mathrm{C}_{\mathrm{Cr}}{ }^{\circ}\right)$ for alloys of interest $[2,3,4,5,6,7,8,9]^{*}$

\begin{tabular}{|c|c|c|c|c|c|c|c|c|c|c|c|c|c|c|}
\hline Alloy & $\mathrm{Fe}$ & $\mathrm{Cr}$ & $\mathrm{Ni}$ & $\mathrm{Co}$ & Mo & $\mathrm{C}$ & $\mathrm{Si}$ & $\mathrm{Ti}$ & $\mathrm{Al}$ & $\begin{array}{r}\mathrm{B} \\
\mathrm{ppm}\end{array}$ & $\mathrm{Mn}$ & Other & $\begin{array}{r}\text { Density } \\
\mathrm{g} / \mathrm{cm}^{3}\end{array}$ & $\begin{array}{r}\mathrm{C}_{\mathrm{Cr}} \\
\mathrm{mol} / \mathrm{m}^{3}\end{array}$ \\
\hline $\begin{array}{l}\text { Haynes } \\
230\end{array}$ & 1.5 & 22 & $\mathrm{Bal}$ & 2.5 & 2 & 0.1 & 0.4 & & 0.3 & 75 & 0.5 & $\begin{array}{r}0.02 \mathrm{La} \\
14 \mathrm{~W}\end{array}$ & 8.97 & 0.0380 \\
\hline $\begin{array}{l}\text { Haynes } \\
282\end{array}$ & 0.75 & 19.5 & $\mathrm{Bal}$ & 10 & 8.5 & 0.06 & 0.075 & 2.1 & 1.5 & 50 & & $0.15 \mathrm{Cu}$ & 8.27 & 0.0310 \\
\hline $\begin{array}{l}\text { Inconel } \\
617\end{array}$ & 1.5 & 22 & Bal & 12.5 & 9 & 0.1 & 0.5 & 0.3 & 1.15 & 30 & 0.5 & $0.25 \mathrm{Cu}$ & 8.36 & 0.0354 \\
\hline $\begin{array}{l}\text { Inconel } \\
625\end{array}$ & 2.5 & 21.5 & $\mathrm{Bal}$ & 0.5 & 9 & 0.05 & 0.25 & 0.2 & 0.2 & & 0.25 & $3.65 \mathrm{Nb}$ & 8.44 & 0.0349 \\
\hline $\begin{array}{l}\text { Inconel } \\
718\end{array}$ & Bal & 19 & 52 & 0.5 & 3.05 & 0.04 & 0.175 & 0.9 & 0.5 & 30 & 0.175 & $\begin{array}{r}5.125 \mathrm{Nb} \\
0.15 \mathrm{Cu}\end{array}$ & 8.19 & 0.0299 \\
\hline $\begin{array}{l}\text { Inconel } \\
740\end{array}$ & 0.7 & 25 & Bal & 20 & 0.5 & 0.03 & 0.5 & 1.8 & 0.9 & & 0.3 & $2 \mathrm{Nb}$ & 8.05 & 0.0387 \\
\hline $\begin{array}{l}\text { Nimonic } \\
105\end{array}$ & 0.5 & 14.85 & Bal & 20 & 5 & 0.085 & 0.5 & 1.2 & 4.7 & 65 & 0.5 & $\begin{array}{r}0.075 \mathrm{Zr} \\
0.1 \mathrm{Cu}\end{array}$ & 8.01 & 0.0229 \\
\hline $\begin{array}{l}\text { Udimet } \\
720 \mathrm{Li}\end{array}$ & & 16 & $\mathrm{Bal}$ & 14.75 & 3 & 0.015 & & 5 & 2.5 & 150 & & $\begin{array}{r}1.25 \mathrm{~W} \\
0.0375 \mathrm{Zr}\end{array}$ & 8.08 & 0.0249 \\
\hline
\end{tabular}

"Source values that were ranges are listed as the midpoint of the range. Source values that were maximums are listed as half the maximum. Only $\mathrm{Nb}$ is listed for sources that gave a value or range for $\mathrm{Nb}+\mathrm{Ta}$. Source values for $\mathrm{Pb}, \mathrm{P}$, and $\mathrm{S}$ are omitted.

Evaporation can change the overall oxidation kinetics from parabolic behavior to linear kinetics or even to breakaway oxidation. Linear kinetics can arise after scale growth from oxidation, which decreases with increasing scale thickness, matches the scale loss from reactive evaporation. The change in scale thickness, $x$, with time, $t$, can then be described in terms of the parabolic rate constant, $\mathrm{k}_{\mathrm{p}}$, and the linear reactive evaporation rate, $\mathrm{k}_{\mathrm{e}}$, as:

$$
\frac{d x}{d t}=\frac{k_{p}}{x}-k_{e}
$$

At long times or high reactive evaporation rates, a limiting scale thickness, $\mathrm{x}_{\mathrm{L}}$, arises that is given by:

$$
x_{L}=\frac{k_{p}}{k_{e}}
$$

In this case metal loss rates are linear, but still involve diffusion through a protective scale. Rapid metal loss can occur when reactive evaporation of $\mathrm{Cr}$ depletes the scale (and sometimes the substrate metal) of $\mathrm{Cr}[11,12]$. Decreased $\mathrm{Cr}$ in the scale or metal can lead to the formation of less protective oxides, such as $\mathrm{Fe}-\mathrm{Cr}$ oxides in $\mathrm{Fe}-\mathrm{Cr}$ base alloys. Unprotective scales can lead to rapid metal loss, or "break-away" oxidation.

A detailed methodology for calculating evaporation rates in a variety of environments was presented in earlier work [10] for gas flow over a flat plate. Two basic equations were developed: Eq. 4 for laminar flow and Eq. 5 for turbulent flow:

$$
k_{e}\left(\frac{\mathrm{kg}}{\mathrm{m}^{2} \mathrm{~s}}\right)=0.664 \operatorname{Re}_{\mathrm{L}}^{0.5} \mathrm{Sc}^{0.343} \frac{D_{\mathrm{AB}} M_{\mathrm{CrO}_{2}(\mathrm{OH})_{2}}}{L R T} P_{\mathrm{CrO}_{2}(\mathrm{OH})_{2}}
$$

$$
k_{e}\left(\frac{k g}{m^{2} s}\right)=0.0592 \operatorname{Re}_{L}^{0.8} S^{0.333} \frac{D_{A B} M_{\mathrm{CrO}_{2}(\mathrm{OH})_{2}}}{L R T} P_{\mathrm{CrO}_{2}(\mathrm{OH})_{2}}
$$

where $\operatorname{Re}_{\mathrm{L}}$ and Sc are the dimensionless Reynolds and Schmidt numbers, $\mathrm{D}_{\mathrm{AB}}$ is the gaseous diffusion coefficient between $\mathrm{CrO}_{2}(\mathrm{OH})_{2}$ and the solvent gas $\left(\mathrm{m}^{2} / \mathrm{s}\right), \mathrm{M}_{\mathrm{CrO} 2(\mathrm{OH}) 2}$ is the molecular mass of $\mathrm{CrO}_{2}(\mathrm{OH})_{2}(\mathrm{~kg} / \mathrm{g}-\mathrm{mol}), \mathrm{L}$ is the length $(\mathrm{m})$ in the flow direction of the flat plate, $\mathrm{P}_{\mathrm{CrO} 2(\mathrm{OH}) 2}$ is the partial pressure of $\mathrm{CrO}_{2}(\mathrm{OH})_{2}(\mathrm{~atm}), \mathrm{R}$ is the gas constant $\left(8.20594 \times 10^{-5} \mathrm{~m}^{3} \mathrm{~atm} / \mathrm{K}\right.$ g$\mathrm{mol})$, and $\mathrm{T}$ is the absolute temperature $(\mathrm{K})$. The dimensionless Reynolds and Schmidt numbers are defined as:

$$
\begin{aligned}
& R e_{L}=\frac{\rho_{s} u L}{\eta} \\
& S C=\frac{\eta}{\rho_{s} D_{A B}}
\end{aligned}
$$

where $\rho_{\mathrm{s}}$ is the density of the solvent gas $\left(\mathrm{kg} / \mathrm{m}^{3}\right), \eta$ is the absolute viscosity $(\mathrm{kg} / \mathrm{m} / \mathrm{s})$, and $u$ is the gas velocity $(\mathrm{m} / \mathrm{s})$. The Gibbs energy for reaction 1 was used to determine $\mathrm{P}_{\mathrm{CrO} 2(\mathrm{OH}) 2 \text {, and the }}$ Gindorf et al. data [13] for the formation of $\mathrm{CrO}_{2}(\mathrm{OH})_{2}(\mathrm{~g})$ was found to best agree with experimental oxidation kinetics [10].

In order to later expand the above methodology for use in pipes and to include possible saturation effects, it is useful to rewrite Eqs. 4-5 in more general terms that include the average Sherwood number $\left(\mathrm{Sh}_{\mathrm{Ave}}\right)$ and to allow for the value of the partial pressure of $\mathrm{CrO}_{2}(\mathrm{OH})_{2}(\mathrm{~g})$ well away from the metal surface, $\mathrm{P}_{\mathrm{CrO} 2(\mathrm{OH}) 2}$, to slow down the evaporation (Eqs. $4-5$ assumed $\mathrm{P}_{\mathrm{CrO} 2(\mathrm{OH}) 2}$ was zero):

$$
k_{e}\left(\frac{k g}{m^{2} s}\right)=S h_{A v e} \frac{D_{A B} M_{\mathrm{CrO}_{2}(\mathrm{OH})_{2}}}{L R T}\left(P_{\mathrm{CrO}_{2}(\mathrm{OH})_{2}}-P_{\mathrm{CrO}_{2}(\mathrm{OH})_{2}}^{\circ}\right)
$$


where $\mathrm{Sh}_{\mathrm{Ave}}$ is equal to $0.664 \mathrm{Re}_{\mathrm{L}}{ }^{0.5} \mathrm{Sc}^{0.343}$ for laminar flow over flat plates and to $0.0592 \mathrm{Re}_{\mathrm{L}}{ }^{0.8} \mathrm{Sc}^{0.333}$ for turbulent flow over flat plates.

For flow within circular tubes, Eq. 8 is used but with different expressions for $\mathrm{Sh}_{\text {Ave }}$. For the analysis that follows, the DittusBoelter equation $[14,15]$ was used for $\mathrm{Sh}_{\mathrm{Ave}}$ for turbulent conditions:

$$
S h_{\text {Ave }}=0.023 R e_{d}^{0.8} S c^{0.4}
$$

where $\operatorname{Re}_{\mathrm{d}}$ is the same as $\mathrm{Re}_{\mathrm{L}}$ but with the diameter, $\mathrm{d}$, instead of the plate length, L, in Eq. 6. For rough pipes the use of an expression for $\mathrm{Sh}_{\mathrm{Ave}}$ that incorporates a friction factor, such as that of Petukov $[15,16]$ can be used.

\section{Chromium Diffusion}

After evaporation causes the overall oxidation kinetics to become linear and to have a steady state scale thickness (Eq. 3), the flux of $\mathrm{Cr}$ away from the scale via evaporation must equal the flux of $\mathrm{Cr}$ to the scale via $\mathrm{Cr}$ diffusion within the alloy. If there is insufficient arrival of $\mathrm{Cr}$ to the surface, then the chromia scale will not be maintained and breakaway oxidation would be expected to eventually occur.

To model Cr diffusion within the alloy with a constant flux of $\mathrm{Cr}$ leaving the surface, the transient heat transfer model of Incropera and DeWitt [15] within a semi-infinite solid and with a constant surface heat flux was used. The underlying mathematics between heat and mass transfer are the same, and so this model could be used with appropriate mass transfer parameters. The overall equation for the concentration of $\mathrm{Cr}$ as a function of $\mathrm{x}$ (depth from the surface into the alloy, $\mathrm{m}$ ) and $\mathrm{t}(\mathrm{time}, \mathrm{s}), \mathrm{C}_{\mathrm{Cr}}(\mathrm{x}, \mathrm{t})$ is:

$$
\begin{aligned}
C_{\mathrm{Cr}}(x, t)= & C_{\mathrm{Cr}}^{\circ}-\frac{2 k_{e}}{M_{\mathrm{CrO}_{2}(\mathrm{OH})_{2}}} \sqrt{\frac{t}{\pi D_{\mathrm{Cr}}}} \exp \left(-\frac{x^{2}}{4 D_{\mathrm{Cr}} t}\right) \\
& +\frac{k_{e} x}{M_{\mathrm{CrO}_{2}(\mathrm{OH})_{2}} D_{\mathrm{Cr}}} \operatorname{erfc}\left(\frac{x}{2 \sqrt{D_{\mathrm{Cr}} t}}\right)
\end{aligned}
$$

where $\mathrm{C}_{\mathrm{Cr}}{ }^{\circ}$ is the bulk alloy $\mathrm{Cr}$ concentration $\left(\mathrm{mol} / \mathrm{m}^{3}\right), \mathrm{D}_{\mathrm{Cr}}$ is the diffusion coefficient of $\mathrm{Cr}\left(\mathrm{m}^{2} / \mathrm{s}\right)$, and erfc is the complementary error function. For the concentration of $\mathrm{Cr}$ at the surface as a function of time, Eq. 10 simplifies to:

$$
C_{C r}(0, t)=C_{\mathrm{Cr}}^{\circ}-\frac{2 k_{e}}{M_{\mathrm{CrO}_{2}(\mathrm{OH})_{2}}} \sqrt{\frac{t}{\pi D_{C r}}}
$$

And the surface concentration is equal to zero at time $\mathrm{t}^{*}$ :

$$
t^{*}=\frac{\pi D_{\mathrm{Cr}}}{4}\left(\frac{M_{\mathrm{CrO}_{2}(\mathrm{OH})_{2}} C_{\mathrm{Cr}}^{\circ}}{k_{e}}\right)^{2}
$$

Breakaway oxidation would be expected to occur prior to $t^{*}$, such as when the surface concentration becomes less than some critical value. There is no universally accepted critical surface concentration, but it cannot be less than zero. So $t^{*}$ is used as a proxy for the time until breakaway oxidation will occur.

At the temperatures in a steam turbine, the diffusion coefficient, $\mathrm{D}_{\mathrm{Cr}}$, is an effective diffusion coefficient and is a combination of lattice, $\mathrm{D}_{\mathrm{Cr}}^{\mathrm{L}}$, and grain boundary, $\mathrm{D}_{\mathrm{Cr}}^{\mathrm{gb}}$, diffusion. The relationship used [17] is based on cubic grains of size $\lambda(\mathrm{m})$ and with grain boundary width $\delta(\mathrm{m})$ :

$$
D_{C r} \cong D_{C r}^{L}+\frac{2 \delta}{\lambda} D_{C r}^{g b}
$$

The lattice diffusion coefficients were determined using Dictra diffusion simulation software [18] with the Ni-DATA [19] and MOB2 [20] databases. Figure 1 shows lattice diffusion coefficients of $\mathrm{Cr}$ in the face centered cubic (FCC) phase for alloys of interest as a function of $\mathrm{Cr}$ content at $760{ }^{\circ} \mathrm{C}$. The rightmost-point for each alloy is at the alloy $\mathrm{Cr}$ content. The lower $\mathrm{Cr}$ content values represent the alloy where it is locally depleted in $\mathrm{Cr}$ near the surface. Figure 1 shows that for many of the alloys an assumption of a constant value for the diffusion coefficient is a good one.

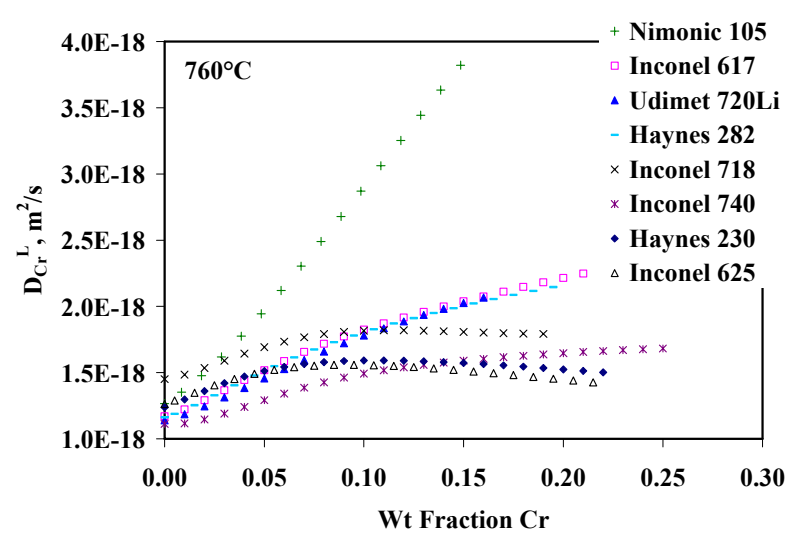

Figure 1. Lattice diffusion coefficients at $760^{\circ} \mathrm{C}$ for $\mathrm{Cr}$ in the FCC phase of nickel base superalloys determined using Dictra diffusion simulation software [18] with the Ni-DATA [19] and MOB2 [20] databases.

The use of the FCC phase as the basis of lattice diffusion is a simplification of the rather complex nature of these alloys. All of the alloys in Table I are strengthened by the formation of one or more second phases, the amount of which depend upon heat treatment [2-9]. Two of these alloys (Nimonic 105 and Udimet $720 \mathrm{Li}$ ) have very significant amounts of a second phase (gamma prime). Further phase complications can arise from $\mathrm{Cr}$ depletion, where the loss of $\mathrm{Cr}$ can itself lead to phase changes. An example of this can be seen in Fig. 2, for Inconel 617 exposed to 2000 hourly cycles at $760{ }^{\circ} \mathrm{C}$ in air with $37 \% \mathrm{H}_{2} \mathrm{O}$ at atmospheric pressure. Each hourly cycle consisted of $55 \mathrm{~min}$ in the furnace and $5 \mathrm{~min}$ out of the furnace. More experimental details can be found in prior work [21]. Figure 2 shows a phase transition zone near the oxide interface, presumably from $\mathrm{Cr}$ depletion. Internal oxidation, mainly of aluminum, is also present underneath the oxide scale along grain boundaries. Thus, a more comprehensive phase-based treatment of diffusion coefficients may be warranted. However, for the calculations that follow (for Haynes 230 and 
Inconel 740), the values used for the lattice diffusion coefficients are ones from the FCC phase at the $\mathrm{Cr}$ content of the alloy (Fig. $1)$.

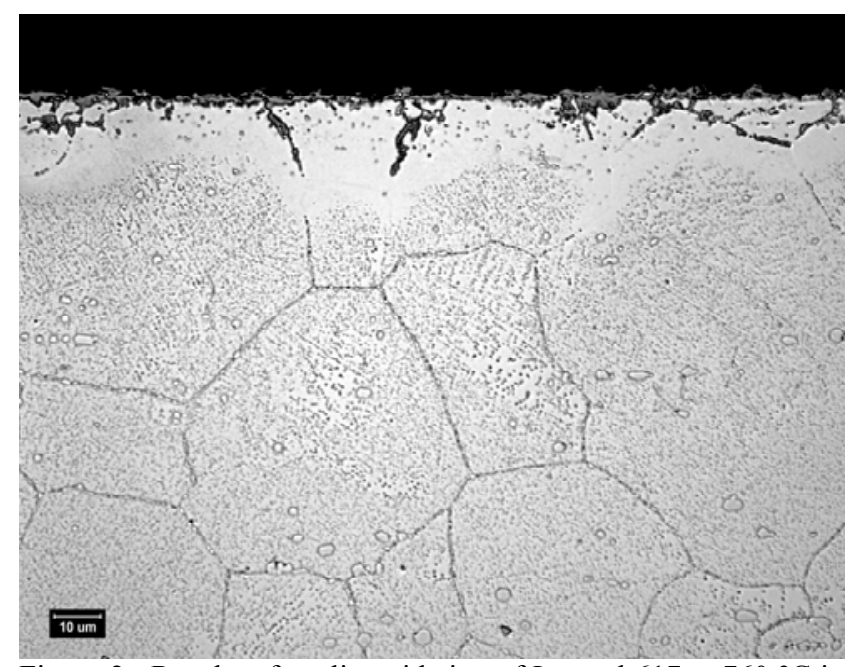

Figure 2. Results of cyclic oxidation of Inconel 617 at $760{ }^{\circ} \mathrm{C}$ in air plus $37 \% \mathrm{H}_{2} \mathrm{O}$ after 2000 hourly cycles. This is a bright field image after etching (50\% concentrated nitric acid, 50\% glacial acetic acid).

Grain boundary diffusion coefficients are estimated based on the work of Paul et al. [22] where lattice and grain boundary diffusion coefficients were determined for Inconel 800 (where a grain boundary width of $0.5 \mathrm{~nm}$ was used). The estimate is to use the same ratio of grain boundary diffusion to lattice diffusion that was found for Inconel 800, and to use the same grain boundary width of $0.5 \mathrm{~nm}$. This ratio is given by Eq. 14:

$$
\frac{D_{C r}^{g b}}{D_{C r}^{L}} \cong \exp \left(\frac{12412}{T}-1.7203\right)
$$

An example of a comparison between calculated and measured $\mathrm{Cr}$ diffusion profiles is given in Fig. 3 for Inconel 740 exposed to 2000 hourly cycles at $760{ }^{\circ} \mathrm{C}$ (under the same conditions as in Fig 2.). The predicted $\mathrm{CrO}_{2}(\mathrm{OH})_{2}$ evaporation rate was $2.13 \times 10^{-9}$ $\mathrm{kg} / \mathrm{m}^{2} \mathrm{~s}$ [10]. The top part of Fig. 3 is a backscattered electron image of a cross section of the metal-scale interface. It shows a very thin oxide scale and a larger thickness of internal oxidation. The internal oxidation is primarily of aluminum. The bottom part of Fig. 3 shows the $\mathrm{Cr}$ concentration profile measured using X-ray photoelectron spectroscopy (points) and the results of the model of Eqs. 10 and 14 with $\lambda$ equal to $30 \mu \mathrm{m}$ and $\delta$ equal to $0.5 \mathrm{~nm}$ (line). The model is a close fit to the measured points, with the model showing a bit less $\mathrm{Cr}$ depletion at the metal scale interface than the measured points.

Other alloys exposed in the same conditions exhibited even more Cr depletion than Inconel 740 did (and more deviation from Eq. 10). However, Eq. 10 only considers $\mathrm{Cr}$ depletion from evaporation. Until the steady state conditions of Eq. 3 are met, the alloy is being oxidized at a faster rate than evaporation would indicate. This initial oxidation is an additional source of $\mathrm{Cr}$ depletion, so measured $\mathrm{Cr}$ profiles should show more $\mathrm{Cr}$ depletion than is found simply by using Eq. 10. Inconel 740 has a smaller $\mathrm{k}_{\mathrm{p}}$ than the other alloys of interest [21], so it lost less Cr to scale formation (and thus less deviation from Eq. 10 than the other alloys).
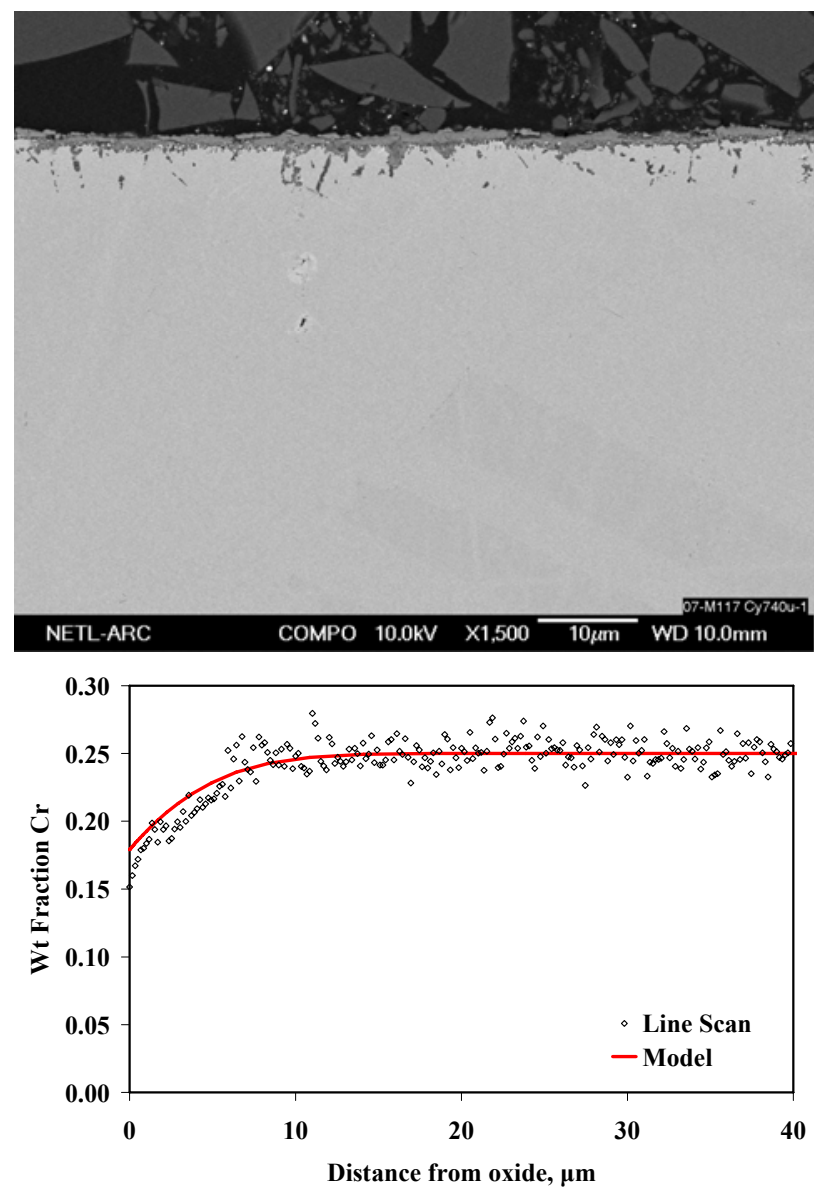

Figure 3. Results of cyclic oxidation of Inconel 740 at $760{ }^{\circ} \mathrm{C}$ in air plus $37 \% \mathrm{H}_{2} \mathrm{O}$ after 2000 hourly cycles. The top image is a backscattered electron image of the cross section. The bottom plot shows the $\mathrm{Cr}$ depletion profile from experiment (points) and Eq. 10 (line).

\section{Hypothetical Superheater-Steam Pipe-HP Turbine Steam Path}

The combination of gas evaporation of $\mathrm{CrO}_{2}(\mathrm{OH})_{2}$, gas saturation of $\mathrm{CrO}_{2}(\mathrm{OH})_{2}$, and $\mathrm{Cr}$ depletion in the alloy is illustrated in Fig. 4. Figure 4 represents one section of superheater $(\mathrm{SH})$ tubing or steam pipe of cell length $\mathrm{L}$. The bulk partial pressure of $\mathrm{CrO}_{2}(\mathrm{OH})_{2}$ coming into the cell is $\mathrm{P}_{\mathrm{CrO} 2(\mathrm{OH}) 2}{ }^{\circ}$. Evaporation within the cell at rate $\mathrm{k}_{\mathrm{e}}$ raises the outgoing $\mathrm{P}_{\mathrm{CrO} 2(\mathrm{OH}) 2}{ }^{\circ}$ by the amount released by evaporation and is shown in Eq. 15.

$$
P_{\mathrm{CrO}_{2}(\mathrm{OH})_{2}}^{\circ}=P_{\mathrm{CrO}_{2}(\mathrm{OH})_{2}}^{\circ}+\frac{4 k_{e} L R T}{d u M_{\mathrm{CrO}_{2}(\mathrm{OH})_{2}}}
$$

The effects of saturating the gas phase with $\mathrm{CrO}_{2}(\mathrm{OH})_{2}$ can then be calculated along the length of a $\mathrm{SH}$ tube or steam pipe by combining many cells together. A hypothetical arrangement of a $100 \mathrm{~m}$ long, $0.05 \mathrm{~m}$ I.D., $\mathrm{SH}$ that leads into a $50 \mathrm{~m}$ long, $0.3 \mathrm{~m}$ 
I.D., steam pipe that leads to a high pressure (HP) turbine is illustrated in Fig. 5. The temperature profile and steam velocities are shown on the left-hand axis, while the evaporation rate is shown on the right-hand axis. The $\mathrm{SH}$ and steam pipe each consisted of 160 cells of the type shown in Fig. 4. Saturation results in a $80 \%$ reduction in the evaporation rate at the HP turbine.

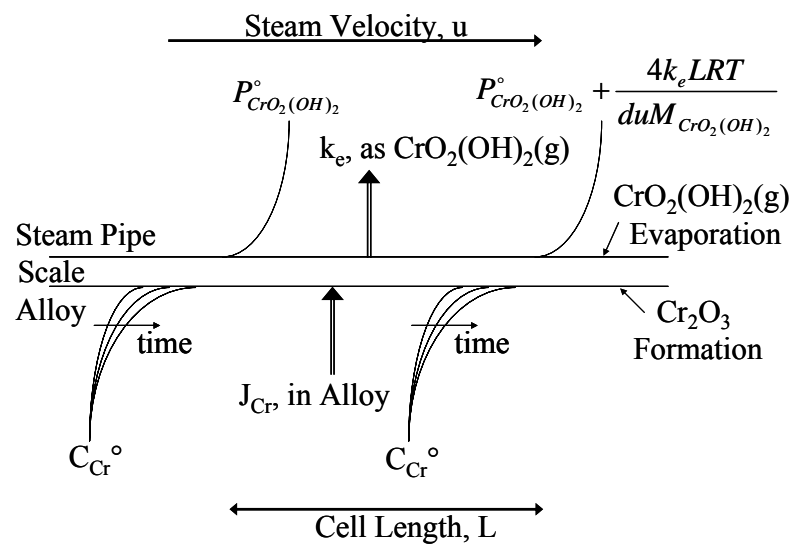

Figure 4. The combination of gas evaporation of $\mathrm{CrO}_{2}(\mathrm{OH})_{2}$, gas saturation of $\mathrm{CrO}_{2}(\mathrm{OH})_{2}$, and $\mathrm{Cr}$ depletion in the alloy is illustrated. This represents one section of superheater tubing or steam pipe of cell length $\mathrm{L}$.

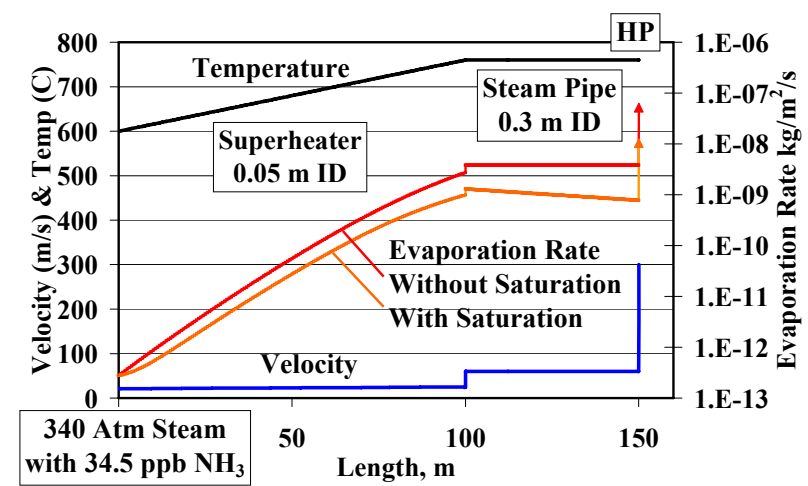

Figure 5 . The effects of gas saturation is shown for a hypothetical arrangement of a $100 \mathrm{~m}$ long SH that leads into a $50 \mathrm{~m}$ steam pipe that leads to a high pressure (HP) turbine. Saturation results in a $80 \%$ reduction in the evaporation rate at the HP turbine.

The time for the alloy $\mathrm{Cr}$ level to reach zero at the scale-metal interface, using Eq. 12, is shown in Fig. 6 for the same conditions as in Fig. 5 (and using saturated values for $\mathrm{k}_{\mathrm{e}}$ ). Haynes 230 was the alloy used. At these conditions, the chromia evaporation at the HP turbine blade is expected to be so great as to deplete the alloy surface of $\mathrm{Cr}$ in a few days. The steam pipe inlet is the area of next concern with the time to zero $\mathrm{Cr}$ at the alloy surface being predicted to be about 1 year.

The very high temperatures and total pressures of Figs. 5-6 match that of the U. S. Department of Energy's goals of $760{ }^{\circ} \mathrm{C}$ and 340 atm. The impact of evaporation at lower temperatures and pressures can be seen in Figs. 7-8, where similar procedures are used to estimate the time it takes for the surface concentration of $\mathrm{Cr}$ in the alloy to reach zero. In all cases the $\mathrm{SH}$ inlet temperature was taken to be $600{ }^{\circ} \mathrm{C}$. Below $600{ }^{\circ} \mathrm{C}$, ferritic alloys, which would not be expected to form chromia scales, would typically be used.

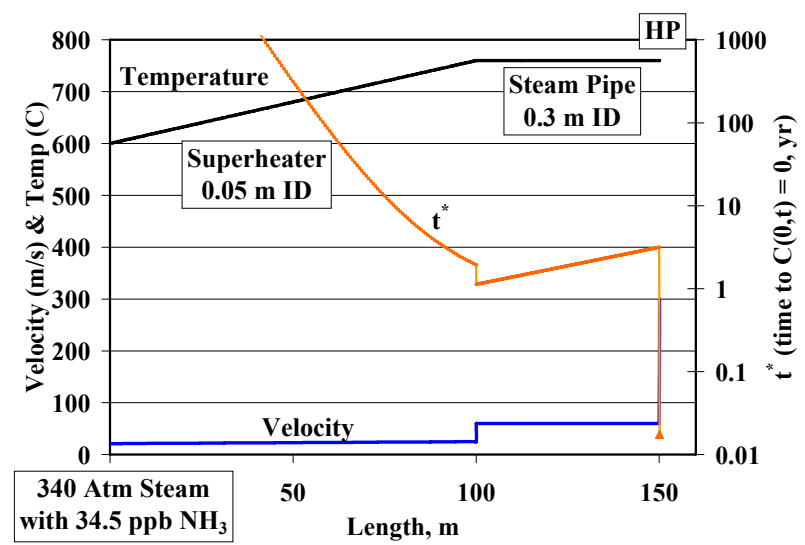

Figure 6. The predicted time for the $\mathrm{Cr}$ level at the scale-metal interface to reach zero.

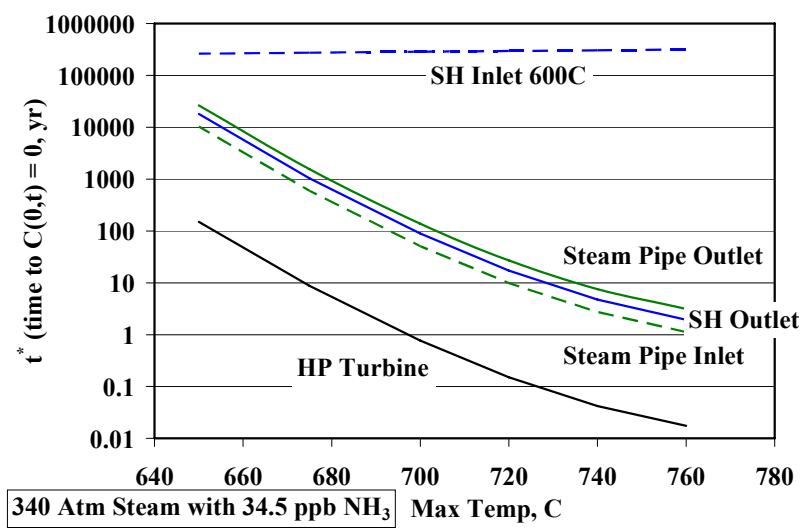

Figure 7. The effects of temperature on the estimate of the time it takes for the surface concentration of $\mathrm{Cr}$ in the alloy to reach zero, at $340 \mathrm{~atm}$.

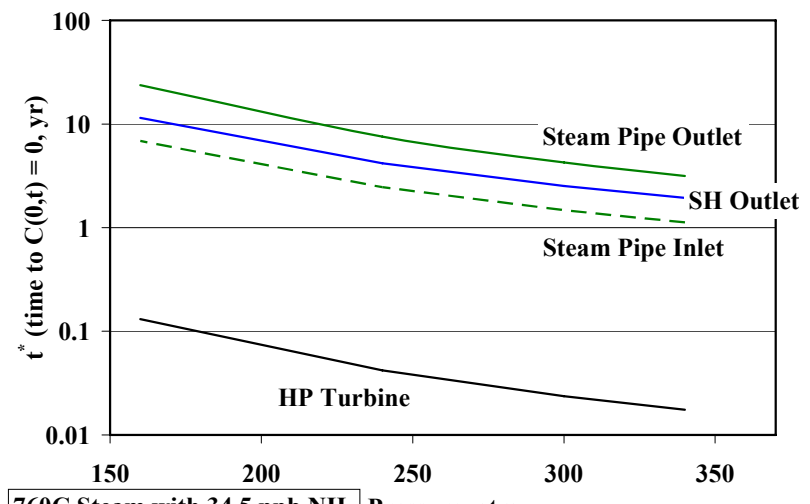

760C Steam with $34.5 \mathrm{ppb} \mathrm{NH}_{3}$ Pressure, atm

Figure 8 . The effects of pressure on the estimate of the time it takes for the surface concentration of $\mathrm{Cr}$ in the alloy to reach zero, at $760{ }^{\circ} \mathrm{C}$. 
Figure 7 shows why chromia evaporation is not considered to be of much concern in existing steam boilers and turbines. Modern advanced steam cycles are currently no higher than $630{ }^{\circ} \mathrm{C}$, so the time to breakaway oxidation (for which the time for $\mathrm{C}(0, \mathrm{t})$ to reach 0 is being used as an estimate) is well beyond the life span of the boiler or turbine. Another factor limiting chromia evaporation in modern advance steam cycles is that ferritic steels are extensively used, and they do not form pure chromia scales. So the activity of $\mathrm{Cr}$ is lower in the scales, which from Eq. 1 lowers the partial pressure of $\mathrm{CrO}_{2}(\mathrm{OH})_{2}(\mathrm{~g})$, which in turn decreases chromia evaporation (Eq. 8).

\section{Mitigation}

Mitigation of these predicted high evaporation rates can be speculated upon. One way could be to reduce the activity of $\mathrm{Cr}$ in the oxide scale in similar ways as used in solid oxide fuel cell (SOFC) interconnect development. For example, enough Mn additions to result in outer scales of $\mathrm{Mn}-\mathrm{Cr}$ spinels instead of chromia is expected to reduce the evaporation of $\mathrm{Cr}$ by a factor of 55 at $700{ }^{\circ} \mathrm{C}[23]$. However, other properties of the alloy would have to be maintained. For example, Mn alloy additions generally reduce the high temperature creep strength of steels [24], so Mn additions are not expected to be used in these applications. But it is possible that other alloying additions could reduce chromia evaporation and not be detrimental to other properties.

High pressure section turbine blades, with their very high predicted evaporation rates at the desired temperatures and pressures would require more in the way of mitigation. Coatings for these HP turbine blades are already being speculated upon, mainly for erosion protection from upstream components (such as from exfoliation of magnetite and hematite scales in boiler water walls). A thermal barrier coating (TBC), such as one based on yttria stabilized zirconia (YSZ), may be able to protect the blade from both erosion and $\mathrm{Cr}$ evaporation.

\section{Future Work}

Laboratory testing of corrosion behavior is ideally performed in the same environment as the expected service conditions. In the case of USC steam turbine environments, such laboratory tests at high temperatures, pressures, and steam velocities would be prohibitively expensive. Alternative laboratory tests were designed to show specific corrosion mechanisms of the type seen under service conditions. Two types of experiments are planned. The first will have exposures to steam at high pressures and temperatures in an autoclave, Fig. 9. The second will be the use of an erosion test rig, used without an erodent, to expose samples in moist air with a relatively high gas velocity, Fig. 10. The samples rotate on the perimeter of the disk, which results in an effective gas velocity of up to $40 \mathrm{~m} / \mathrm{s}$.

The autoclave tests in high-temperature and high-pressure steam should show the type of chromia scale formation that would occur without appreciable chromia evaporation. The rotating disk tests should show similar evaporation rates that would be expected in the USC HP turbine. The basis for these two predictions are in Figure 11, which shows the expected evaporation rates for the USC HP turbine (without saturation effects), low gas flow laboratory experiments (for a wide range of oxygen partial pressures), and rotating disk experiments (in air with 3\%-50\% $\mathrm{H}_{2} \mathrm{O}$ ). Figure 11 indicates that exposures in steam (with low oxygen contents) at low laboratory-type flows would not result in measurable evaporation rates. However, $40 \mathrm{~m} / \mathrm{s}$ exposures in air with $3 \%$ to $50 \% \mathrm{H}_{2} \mathrm{O}$ should result in evaporation rates that are similar to those expected to occur in USC HP turbines. These rotating disk exposures will serve as validation of the chromia evaporation model in turbulent conditions.

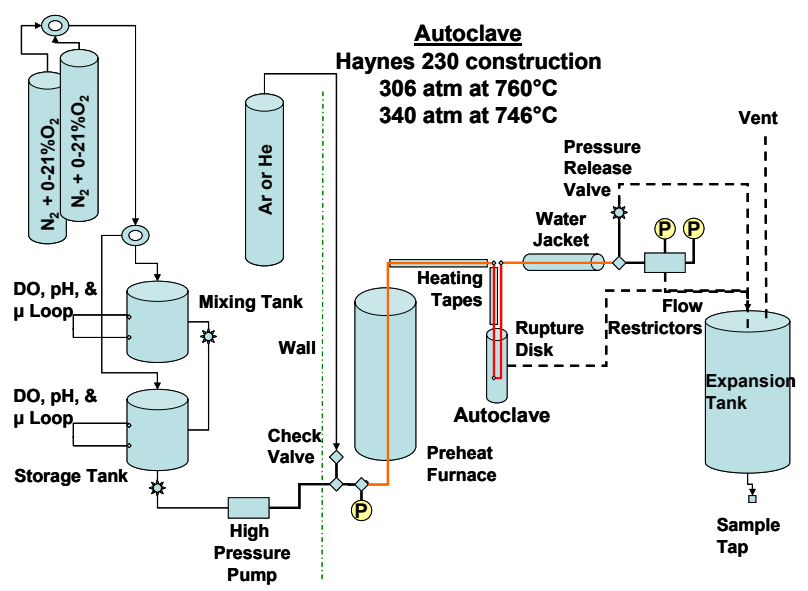

Figure 9. Autoclave apparatus for exposures in steam at up to either $306 \mathrm{~atm}$ at $760{ }^{\circ} \mathrm{C}$ or $340 \mathrm{~atm}$ at $746{ }^{\circ} \mathrm{C}$.

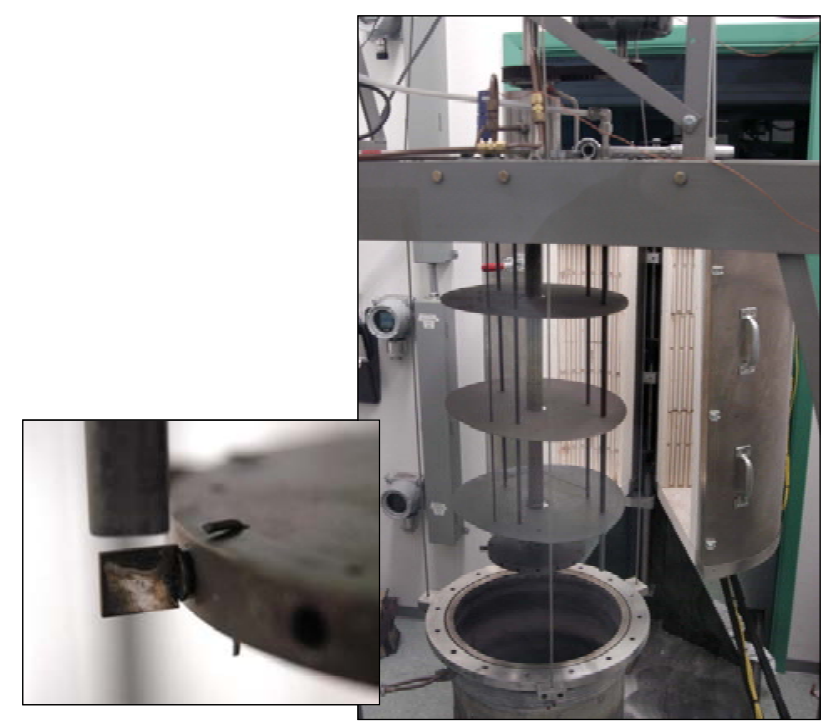

Figure 10. Rotating disk apparatus for exposures in moist air at speeds of up to $40 \mathrm{~m} / \mathrm{s}$. This erosion test rig will be used without erodent in model validation tests.

\section{Conclusions}

A methodology that was earlier developed to calculate $\mathrm{Cr}$ evaporation rates from $\mathrm{Cr}_{2} \mathrm{O}_{3}$ with a flat planar geometry [10], was expanded upon to allow for interior cylindrical geometries, and to allow for the effects of $\mathrm{CrO}_{2}(\mathrm{OH})_{2}$ saturation within the gas phase. This approach was combined with $\mathrm{Cr}$ diffusion calculations within the alloy (with a constant flux of $\mathrm{Cr}$ leaving the alloy from evaporation) to predict $\mathrm{Cr}$ concentration profiles as a function of exposure time and to predict the time until the alloy 
surface concentration of $\mathrm{Cr}$ reaches zero. This time is a rough prediction of the time until breakaway oxidation.

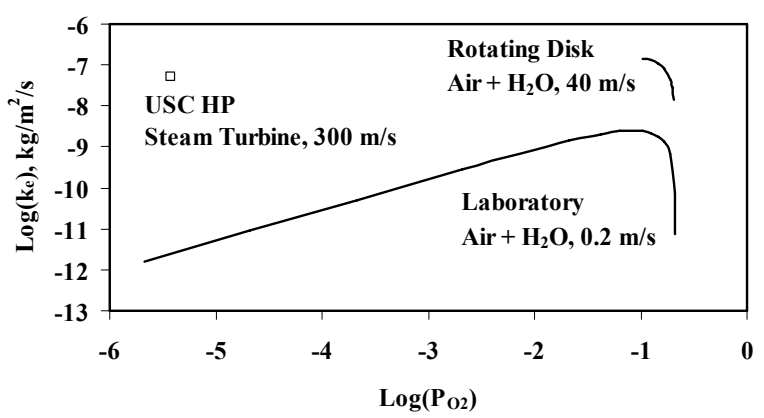

Figure 11. A comparison, at $760^{\circ} \mathrm{C}$, of evaporation rates for USC HP steam turbine conditions (without saturation effects), low gas flow laboratory experiments (for a wide range of oxygen partial pressures), and rotating disk experiments (in air with 3\%-50\% $\mathrm{H}_{2} \mathrm{O}$ ).

A hypothetical super heater ( $\mathrm{SH})$ tube, steam pipe, and high pressure (HP) turbine steam path was assembled and examined with the methodology. At the U. S. Department of Energy's goals of $760{ }^{\circ} \mathrm{C}$ and $340 \mathrm{~atm}$, the time until breakaway oxidation was predicted to be quite short for the turbine blade, and of concern within the steam pipe and the higher temperature portions of the $\mathrm{SH}$ tube. The predicted time until breakaway oxidation increases dramatically with decreases in temperature and total pressure.

Possible mitigation techniques were discussed, including those used in solid oxide fuel cell (SOFC) metallic interconnects (lowering the activity of $\mathrm{Cr}$ in the oxide scale by adding $\mathrm{Mn}$ to the alloy), and thermal barrier coating (TBC) use on HP turbine blades for both erosion and chromia evaporation protection.

\section{References}

1. R. Viswanathan, J.F. Henry, J. Tanzosh, G. Stanko, J. Shingledecker, B. Vitalis, and R. Purgert, "U.S Program on Materials Technology for Ultra-Supercritical Coal Power Plants," Journal of Materials Engineering and Performance, 14 (2005), 281-292.

2. Haynes 230 Alloy, H-3135C (Kokomo, IN: Haynes International, 2008).

3. Haynes 282 Alloy, H-3172A (Kokomo, IN: Haynes International, 2008).

4. Inconel Alloy 617, SMC-029 (Huntington, WV: Special Metals Corporation, 2005).

5. Inconel Alloy 625, SMC-063 (Huntington, WV: Special Metals Corporation, 2006).

6. Inconel Alloy 718, SMC-045 (Huntington, WV: Special Metals Corporation, 2007).
7. Inconel Alloy 740, SMC-090 (Huntington, WV: Special Metals Corporation, 2004).

8. Nimonic Alloy 90, SMC-081 (Huntington, WV: Special Metals Corporation, 2007).

9. Udimet Alloy 720, SMC-106 (Huntington, WV: Special Metals Corporation, 2004).

10. G.R. Holcomb, "Calculation of Reactive Evaporation Rates of Chromia," Oxidation of Metals, 69 (2008), 163-180.

11. H. Asteman, J.-E. Svensson, L.-G. Johansson, and M. Norell, "Indication of Chromium Oxide Hydroxide Evaporation During Oxidation of $304 \mathrm{~L}$ at $873 \mathrm{~K}$ in the Presence of $10 \%$ Water Vapor," Oxidation of Metals, 52 (1999), 95-111.

12. H. Asteman, J.-E. Svensson, M. Norell, and L.-G. Johansson, "Influence of Water Vapor and Flow Rate on the HighTemperature Oxidation of 304L; Effect of Chromium Oxide Hydroxide Evaporation," Oxidation of Metals, 54 (2000), 11-26.

13. C. Gindorf, K. Hilpert, and L. Singheiser, "Determination of Chromium Vaporization Rates of Different Interconnect Alloys by Transpiration Experiments," Solid Oxide Fuel Cells (SOFC VII), Proceedings Vol. 2001-16, ed. H. Yokokawa and S.C. Singhal (Pennington, NJ: Electrochemical Society, 2001), 793802.

14. R.H.S. Winterton, "Where did the Dittus and Boelter Equation Come From?" International Journal of Heat and Mass Transfer, 41 (1998), 809-810.

15. Frank P. Incropera and David P. DeWitt, Fundamentals of Heat and Mass Transfer, 5th Ed. (New York, NY: John Wiley \& Sons, 2001), 268-270, 491-492, 508.

16. B.S. Petukhov, "Heat Transfer and Friction in Turbulent Pipe Flow with Variable Physical Properties," Advances in Heat Transfer, Vol 6, ed. T.F. Irvine and J.P. Hartnett (New York, NY: Academic Press, 1970), 503-564.

17. X. Peng, J. Yan, Y. Zhou and F. Wang, "Effect of Grain Refinement on the Resistance of 304 Stainless Steel to Breakaway Oxidation in Wet Air," Acta Materialia, 53 (2005), 5079-5088.

18. Dictra, Diffusion Simulation Software, Version 24 (Stockholm, Sweden: Thermo-Calc Software AB, 2006).

19. N. Saunders, Ni-DATA, Version 7 (Surrey, UK: Thermotech Ltd, Surrey Technology Centre, 2000).

20. MOB2, Mobility Database, Version 2.0 (Stockholm, Sweden: Royal Institute of Technology, Foundation of Computational Thermodynamics, 1999).

21. G. R. Holcomb, D. E. Alman, Ö. N. Doğan, J. C. Rawers, K. K. Schrems, and M. Ziomek-Moroz, "Steam Turbine Materials and Corrosion," Proceedings of the 21st Annual Conference on Fossil Energy Materials, Knoxville, TN, April 30-May 1, 2007 
(U.S. Department of Energy, Office of Fossil Energy, Advanced Research Materials) 2007.

22. A.R. Paul, K.N.G. Kaimal, M.C. Naik and S.R. Dharwadkar, "Lattice and Grain Boundary Diffusion of Chromium in Superalloy Incoloy-800," Journal of Nuclear Materials, 217 (1994), 75-81.

23. G. R. Holcomb, D. E. Alman, "The Effect of Manganese Additions on the Reactive Evaporation of Chromium in $\mathrm{Ni}-\mathrm{Cr}$ Alloys," Scripta Materialia, 54 (2006), 1821-1825.

24. F. Masuyama, "History of Power Plants and Progress in Heat Resistant Steels," ISIJ International, 41 (2001), 612-625. 